\title{
Research on the Quality Evaluation System of Pharmacy Open Experimental Teaching
}

\author{
Wang Huanqi ${ }^{1}$, Du Peige ${ }^{1}$, Li Zitong ${ }^{1}$, Yuan Guangxin ${ }^{1 *}$ \\ ${ }^{1}$ Pharmacy College of Beihua University, Jilin City, CHINA
}

Received 11 May 2017 • Revised 26 August 2017 • Accepted 28 September 2017

\begin{abstract}
Aim to establish a scientific and reasonable quality evaluation method of pharmacy open experimental teaching mode. Method The pharmacy open experiment is embodied in the forms of amateurism, nature of curriculum and graduation design; three different forms of quality evaluation system are established according to the three different forms of open experimental teaching. Results The established quality evaluation system of pharmacy open experimental teaching mode breaks the traditional single evaluation mode; embodies the student-oriented educational thought; and also conduces to improve the enthusiasm and proactivity of students to participate in the experiment, achieve teaching objectives, and increase teaching quality. Conclusion The research also has certain enlightening effect on the reform of assessment and evaluation mode of pharmacy open experimental teaching of higher education in China.
\end{abstract}

Keywords: pharmacy, open, quality, evaluation, research

\section{INTRODUCTION}

In order to carry out the pharmacy open experimental teaching, we have carried out undergraduate tutorial system in the early stage of practice, and each student has chosen his favorite tutor according to his own interests and hobbies (Lutfi, 2013; Yang et al., 2015). And laboratories and research laboratories are fully opened. From 2008, the practice of pharmacy open experimental teaching mode after class gradually began to be performed from the undergraduate innovation experiment plan. From 2013, the practice of curriculum content type of pharmacy open experimental teaching mode began to be performed, and the "Pharmaceutical Analysis" and "Pharmacy Experimental Study" were selected. From 2014, the practice of pharmacy open experimental teaching mode began to be carried out in the undergraduate graduation design.

Considering that the feature of pharmacy open experimental teaching mode is embodied in the forms of amateurism, curriculum nature and graduation design, we think that the experimental processes and results are both very important. Therefore, the evaluation should not simply take the results as a conclusion, but the following aspects should be synthetically taken into account: evaluating that if the experimental program highlights novelty and originality of the design; evaluating that if the experimental process reflects independence and exerts students' cognitive ability; evaluating that if the experimental program is economical, simple, scientific and reasonable, and can achieve the desired results; and evaluating the form (reports or thesis) and value embodiment of the experimental results. Only by taking these factors into account, can the evaluation of pharmacy open experimental teaching mode be scientific and objective.

\section{LITERATURES REVIEWING}

The pharmacy open experimental teaching is an effective way to cultivate innovative talents. Hu et al. said: the driving force of research is to cultivate students' innovative ability through various effective ways (2016). Some scholars also tried open experimental teaching in the teaching of Fluid Mechanics, Computer, Engineering and other disciplines (Marsico et al., 2017; Price et al., 2017; Schauer et al., 2008). Yet effective utilization of the ways in

(C) Authors. Terms and conditions of Creative Commons Attribution 4.0 International (CC BY 4.0) apply. 


\section{Contribution of this paper to the literature}

- This paper sets up three different forms of quality evaluation system.

- It breaks the current single evaluation mode and embodies the scientificity of the evaluation system.

- This paper according to the different form of the opening experimental teaching, considering the originality and economy of the experimental scheme, the independence of the experimental process, the value embodiment of the experimental results and other factors.

cultivating the students should also be evaluated while looking for the effective ways and objective evaluation criteria should also be developed (Lin et al., 2016; Tarcilo et al., 2013; Zheng et al., 2013). The current research type is single in type, and cannot reflect the comprehensiveness, integration, and innovation of the evaluation. Therefore, how to evaluate the open experiment, so that the evaluation is more scientific and reasonable, and reflects the true value of the experimental quality is the primary problem. The establishment of the quality evaluation system of pharmacy open experimental teaching mode not only embodies the scientific thought of teaching strategy, but also conduces to improve the enthusiasm and proactively of the students to participate in the experiment, and achieve teaching objectives and increase teaching quality.

\section{RESEARCH DESIGN}

According to these three different forms of open experimental teaching, we also established three different forms of quality evaluation system respectively:

(1) The evaluation system established for the open experiments performed after class.

The content of the open experiment performed after class comes from an original topic that the students themselves are interested in, student science and technology competition, a scientific research subject that an undergraduate tutor is responsible for, and the development and improvement of classroom teaching. In the actual operation, it is mainly reflected in various science and technology competitions, and scientific research subjects of undergraduate tutors. After the preliminary working basis, the best program is designed and approved by the tutors. In view of this, the principle of establishing the quality evaluation system is student-centered, and pays attention to students' subjectivation development and individuation development. To this end we have established the following evaluation system, see Table $\mathbf{1}$ :

Table 1. Content and Standard of Quality Evaluation for Open Experiment (after class)

\begin{tabular}{|c|c|c|c|c|c|c|}
\hline \multirow{2}{*}{ Serial No. } & \multirow{2}{*}{ Evaluation Index } & \multirow{2}{*}{ Weight } & \multicolumn{4}{|c|}{ Evaluation Grade } \\
\hline & & & A & B & $\mathbf{C}$ & $\mathbf{D}$ \\
\hline 1 & Time of experiments $(\geq 20, \geq 40, \geq 60, \geq 80 \mathrm{~h})$ & 0.5 & & & & \\
\hline 2 & Documents reading $(\geq 10, \geq 20, \geq 30, \geq 40$ pieces $)$ & 0.5 & & & & \\
\hline 3 & $\begin{array}{l}\text { Operation technology reflecting correctness, proficiency, no } \\
\text { defect and with low repetition rate }\end{array}$ & 1.5 & & & & \\
\hline 4 & Independence of the experimental process & 0.5 & & & & \\
\hline 5 & Whether the experimental process is economical and simple & 0.5 & & & & \\
\hline 6 & Data analysis being scientific, accurate, and logical & 1.0 & & & & \\
\hline 7 & $\begin{array}{c}\text { Expected test results analysis reflecting comprehensiveness } \\
\text { and predictability }\end{array}$ & 1.0 & & & & \\
\hline 8 & Innovativeness & 1.5 & & & & \\
\hline 9 & Experimental report and review & 1.5 & & & & \\
\hline 10 & Achievements (articles, patents, etc.) & 1.5 & & & & \\
\hline Total & & 10 & & & & \\
\hline $\begin{array}{c}\text { Feature } \\
\text { Innovation }\end{array}$ & & $\begin{array}{c}\text { Overall } \\
\text { Evaluation }\end{array}$ & & & & \\
\hline
\end{tabular}

It should be noted that: when a student performing open experiments, his tutor (teacher, graduate student) randomly inspects the student's experiment: whether complies with open experimental code of conduct, whether works properly in accordance with the program, whether needs to address technical problems and how to solve them, and fill the inspection process in the open laboratory record at any time. It is important to participate in this type of open experiment, and the assessment results serve as a part of the innovation quality expansion credits. 
Table 2. Content and Standard of Quality Evaluation for Open Experiment (in curriculum teaching)

\begin{tabular}{|c|c|c|c|c|c|c|}
\hline \multirow{2}{*}{ Serial No. } & \multirow{2}{*}{ Evaluation Index } & \multirow{2}{*}{ Weight } & \multicolumn{4}{|c|}{ Evaluation Grade } \\
\hline & & & $\mathbf{A}$ & B & $\mathbf{C}$ & D \\
\hline 1 & Documents reading $(\geq 5, \geq 10, \geq 15, \geq 20$ pieces $)$ & 0.5 & & & & \\
\hline 2 & Design of the experimental topic & 0.5 & & & & \\
\hline 3 & Group Discussion for the experimental program design & 1.5 & & & & \\
\hline 4 & $\begin{array}{l}\text { Operation technology reflecting correctness, proficiency, no } \\
\text { defect and with low repetition rate }\end{array}$ & 1.5 & & & & \\
\hline 5 & $\begin{array}{l}\text { Teamwork performance and independent spirit in the } \\
\text { experimental process }\end{array}$ & 0.5 & & & & \\
\hline 6 & Whether the experimental process being economical and simple & 0.5 & & & & \\
\hline 7 & Data analysis being scientific, accurate, and logical & 1.0 & & & & \\
\hline 8 & Time of experiments: $\leq 8 \mathrm{~h}$ & 0.5 & & & & \\
\hline 9 & Experiment operating record (Results) & 1.5 & & & & \\
\hline 10 & Experimental report and review & 1.5 & & & & \\
\hline Total & & 10 & & & & \\
\hline $\begin{array}{c}\text { Feature } \\
\text { Innovation }\end{array}$ & & $\begin{array}{c}\text { Overall } \\
\text { Evaluation }\end{array}$ & & & & \\
\hline
\end{tabular}

(2) The evaluation system established for the open experiments performed in the curriculum teaching.

The purpose of performing open experiment in the curriculum teaching is to enable students to take full range of training in mastering basic knowledge, basic methods and basic skills of pharmaceutical experiment; cultivate students' good scientific literacy and team spirit; and make them have the quality and ability to carry out scientific research work independently. After discussion, we initially selected one of the main courses of pharmacy"Pharmaceutical Analysis" for early practice, and the mode is to first select one piece of content of the course to perform open experiments, and then promote the application after accumulating certain experience. For the evaluation system, see Table 2 .

While performing an open experiment of a designated course, it should be noted that: the whole process should be monitored by full-time teachers, and the open experiment should be completed within the prescribed time and accepted by teachers. During the experimental process, the teachers should accept students' questions, indicate an operation error, discrepancies between design and actual operation, and evaluate quality at any time. Students are encouraged to select design tests and advanced pharmaceutical experimental methods, technology. At the same time, each group of students may have different experimental projects, and each student has his own personalized emphasis through open experiment training. Therefore, teachers should take different points and degree of difficulty into account in the assessment process. This open experimental teaching evaluation system pays more attention to the assessment of process.

(3) The evaluation system established for the open experiments performed in the graduation design.

Graduation design is an important part in undergraduate education of regular institutions of higher learning, and it is also an important process for university students to consolidate, synthetically apply and practice the knowledge they have learned and explore new fields. Open experiments for graduation design have a very important guiding role in improving the undergraduates' comprehensive ability and quality. For the evaluation system, see Table 3 .

Students majored in pharmacy generally choose pharmaceutical factories, institutes for drug control, hospitals, research institutes and other related units for graduation practice. Therefore, feasibility of the practice units needs to be considered in the graduation design. Quantification, details of the graduation design, students' selfperception, and evaluation of the practice units should be fully considered in the quality evaluation. While performing the open experiments, students are encouraged to seek advice and suggestions from the teachers designated by the university. 
Table 3. Content and Standard of Quality Evaluation for Open Experiment (in graduation design)

\begin{tabular}{|c|c|c|c|c|c|c|}
\hline \multirow{2}{*}{ Serial No. } & \multirow{2}{*}{ Evaluation Index } & \multirow{2}{*}{ Weight } & \multicolumn{4}{|c|}{ Evaluation Grade } \\
\hline & & & A & B & $\mathbf{C}$ & D \\
\hline 1 & Documents reading $(\geq 20, \geq 30, \geq 40, \geq 50$ pieces $)$ & 0.5 & & & & \\
\hline 2 & $\begin{array}{l}\text { Selection of the graduation design topic, reflection of the } \\
\text { epochal character }\end{array}$ & 0.5 & & & & \\
\hline 3 & $\begin{array}{l}\text { Design of the experimental program reflecting the } \\
\text { innovativeness and practicality }\end{array}$ & 1.0 & & & & \\
\hline 4 & Thesis proposal & 1.0 & & & & \\
\hline 5 & Independent spirit and scientificity in the experimental process & 0.5 & & & & \\
\hline 6 & Data analysis being scientific, accurate, and logical & 1.0 & & & & \\
\hline 7 & $\begin{array}{l}\text { Operation technology reflecting correctness, proficiency, no } \\
\text { defect and with low repetition rate }\end{array}$ & 1.5 & & & & \\
\hline 8 & Mid-term inspection & 1.0 & & & & \\
\hline 9 & Experiment operating record (Results) & 1.5 & & & & \\
\hline 10 & $\begin{array}{c}\text { Design report, graduation thesis (with or without theses, } \\
\text { patents published) }\end{array}$ & 1.5 & & & & \\
\hline Total & & 10 & & & & \\
\hline $\begin{array}{c}\text { Feature } \\
\text { Innovation }\end{array}$ & & $\begin{array}{c}\text { Overall } \\
\text { Evaluation }\end{array}$ & & & & \\
\hline
\end{tabular}

\section{DISCUSSION}

The research results of the predecessors are basically the systematic description on open experiment in different majors, which is single in form and the evaluation criteria and the content thereof are not complete (Cao et al., 2017; Qu et al., 2017; Ying, 2009). Some of the research results emphasis on the reform in content, and other research results emphasis on the change in form (Chen et al., 2017; Zhang et al., 2017). However, in this paper, the pharmacy open experiment is divided into three forms, three kinds of evaluation criteria are established, the inherent differences in amateurism, curriculum nature and graduation design are fully embodied, and evaluation focuses thereof are different, so that the evaluation criteria is more objective and reasonable, scientific and innovative, reflects the correctness in grading, and is operational.

\section{CONCLUSION AND RECOMMENDATION}

The pharmacy open experimental teaching model can improve students' interest in learning and promote the creation of innovative thinking effectively, and it can be effectively guaranteed under the specifically operational quality evaluation system. The establishment of the quality evaluation system of pharmacy open experimental teaching mode not only embodies the student-oriented educational thought, but also conduces to improve the enthusiasm and proactivity of students to participate in the experiment, achieve teaching objectives and increase teaching quality. On this basis, the open laboratory performance evaluation system will also be gradually established, so that the laboratory is targeted constructed and developed in a good direction, and open laboratory construction and development is promoted to a higher level.

\section{ACKNOWLEDGEMENTS}

This paper is supported by the Network Course Construction of Beihua University (2014), School Level Key Teaching Reform Research of Beihua University (2014), Teaching Reform Research of Jilin Province(2015),and Beihua University young teacher promotion program (Beihua University[2016] 43.

\section{REFERENCES}

Chen, Y.-C., Deyi, K. (2017). An Investigation on Factors in the Integration of Reciprocal Teaching into Multimedia Teaching. Eurasia Journal of Mathematics, Science $\mathcal{E}$ Technology Education. 13(1), 133-142. doi:10.12973/eurasia.2017.00608a

De Marsico, M., Sciarrone, F., Sterbini, A., \& Temperini, M. (2017). Supporting Mediated Peer-Evaluation to Grade Answers to Open-Ended Questions Maria. Eurasia Journal of Mathematics, Science E Technology Education. 13(4), 1085-1106. doi:10.12973/eurasia.2017.00660a 
Hu, R., Wu, Y.-Y., Chich-Jen, S. (2016). Effects of Virtual Reality Integrated Creative Thinking Instruction on Students' Creative Thinking Abilities. Eurasia Journal of Mathematics, Science $\mathcal{E}$ Technology Education, 12(3), 477-486. doi:10.12973/eurasia.2016.1226a

Incikabi, L. (2013). Teacher Candidates' Efficacy Beliefs in Mathematics: Play-Generated Curriculum Instruction. Eurasia Journal of Mathematics, Science E Technology Education, 9(2), 167-176. doi:10.12973/eurasia.2013.927a

Lin, G.-Y. (2016). Effects that Facebook-based Online Peer Assessment with Micro-teaching Videos Can Have on Attitudes toward Peer Assessment and Perceived Learning from Peer Assessment. Eurasia Journal of Mathematics, Science \& Technology Education, 12(9), 2295-2307. doi:10.12973/eurasia.2016.1280a

Price, C., van Jaarsveld, P. (2017). Using Open-response Tasks to Reveal the Conceptual Understanding of LearnersLearners Teaching the Teacher what they know about Trigonometry. African Journal of Research in Mathematics Science and Technology Education, 21(2), 159-175. doi:10.1080/18117295.2017.1329054

Qu, S.-Y., Hu, T., Wu, J.-L., Hou, X. M. (2017). “New Engineering” Practice Teaching Mode. Eurasia Journal of $\begin{array}{lllll}\text { Mathematics, Science } \quad \mathcal{E} \text { Technology } & \text { Education, 13(7), }\end{array}$ https://doi.org/10.12973/eurasia.2017.00810a

Schauer, F., Lustig, F., Dvorak, J., \& Ozvoldova, M. (2008). An easy-to-build remote laboratory with data transfer using the Internet School Experimental System. European Journal of Physics, 29(4), 753-765. doi:10.1088/01430807/29/4/010

Torres, T., Milicic, B., Soto, C., \& Sanjose, V. (2013). Generating Students' Information Seeking Questions in the Scholar Lab: What Benefits Can We Expect From Inquiry Teaching Approaches? Eurasia Journal of Mathematics, Science \& Technology Education, 9(3), 259-272. doi:10.12973/eurasia.2013.934a

Yang, K.-T., Wang, T.-H., \& Chiu, M.-H. (2015). Study the Effectiveness of Technology-Enhanced Interactive Teaching Environment on Student Learning of Junior High School Biology. Eurasia Journal of Mathematics, Science \& Technology Education, 11(2):263-275. doi:10.12973/eurasia.2015.1327a

Ying, H. (2009). Research on the Open Experimental Teaching Mode for Computer Major. 2009 International Forum on Computer Science-Technology and Applications, 3, Proceedings 2009, 380-382. doi:10.1109/IFCSTA.2009.331

Yonghui, C., Kirilova, G. I., \& Grunis, M. L. (2017). Cooperative Research Projects of Master's Students (Education Programs) in the Open Informational Educational Environment. Eurasia Journal of Mathematics, Science $\mathcal{E}$ Technology Education, 13(7), 2859-2868. doi:10.12973/eurasia.2017.00722a

Zhang, M. H., Li, Y. (2017). Teaching Experience on Faculty Members' Perceptions about the Attributes of Open Educational Resources (OER). International Journal of Emerging Technologies in Learning, 12(4), 191199. doi:10.3991/ijet.v12i04.6638

Zheng, B., Liu, Y. Q., Liu, R. X., Meng, J. \& Mao, M. M. (2013). Open Experimental Teaching in Fluid Mechanics. Advanced Design and Manufacturing Technology III, PTS, 1-4.2013, 397-400, 2735-2738. doi:10.4028/www.scientific.net/AMM.397-400.2735

\section{http://www.ejmste.com}

